EVEN HOTTER OFF THE BREATH

\section{President elect kidnapped. Tsar very much}

\author{
Andy Bush, lan Pavord
}

Or at least appointed as the new National Clinical Director for Respiratory (our very own Tsar) in the National Commissioning Board. Huge congratulations to Professor Mike Morgan on his appointment, which sadly means he has decided to step down as President Elect of the BTS. So good that someone in such an important role is a true patients' champion, with a proven track record in campaigning for the best for COPD and many other patients, and not a timeserving place person. Could we have a better person for the job? Grievous as is the loss to the BTS, it is made up for by the prospect of having a superb person as respiratory champion, keeping our patients needs on the front burner. As Sheila Edwards said in the BTS news, we have a true Respiratory Champion within the new NHS! Congratulations and tremendous support from us all, we look forward to seeing Mike's manifesto in Thorax, and sincerely hope that he does sometimes get a brief moment with his family.

Competing interests None.

Provenance and peer review Commissioned; internally peer reviewed.

To cite Bush A, Pavord I. Thorax 2013;68:409.

Thorax 2013:68:409.

doi:10.1136/thoraxjnl-2013-203668 